\title{
Separate Determination of Borohydride, Borate, Hydroxide, and Carbonate in the Borohydride Fuel Cell by Acid-Base and Iodometric Potentiometric Titration
}

\author{
A. V. Churikov, S. L. Shmakov, V. O. Romanova, K. V. Zapsis, A. V. Ushakov, \\ A. V. Ivanishchev, and M. A. Churikov \\ Institute of Chemistry, Saratov State University, 83 Astrakhanskaya Street, Saratov 410012, Russia \\ Correspondence should be addressed to V. O. Romanova; nikanor_verona@mail.ru
}

Received 23 May 2013; Accepted 26 November 2013; Published 29 January 2014

Academic Editor: César Sequeira

Copyright (C) 2014 A. V. Churikov et al. This is an open access article distributed under the Creative Commons Attribution License, which permits unrestricted use, distribution, and reproduction in any medium, provided the original work is properly cited.

\begin{abstract}
A methodology for quantitative chemical analysis of the complex "borohydride-borate-hydroxide-carbonate-water" mixtures used as fuel in the borohydride fuel cell was developed and optimized. The methodology includes the combined usage of the acid-base and iodometric titration methods. The acid-base titration method, which simultaneously uses the technique of differentiation and computer simulation of titration curves, allows one to determine the contents of hydroxide (alkali), carbonate, and total "borate + borohydride" content. The iodometric titration method allows one to selectively determine borohydride, so the content of each of $\mathrm{OH}^{-}, \mathrm{BH}_{4}{ }^{-}, \mathrm{BO}_{2}{ }^{-}$, and $\mathrm{CO}_{3}{ }^{2-}$ anions in the fuel becomes estimated. The average determination error depends on the number and ratio of compounds in a mixture. Specific details of the analysis of various fuel mixtures are discussed.
\end{abstract}

\section{Introduction}

The intense progress of electric vehicles, portable electronics, mobile communication tools, and other systems, which require independent power supply, stimulates the design of new chemical power sources $[1,2]$. These sources have to possess high-energy specific characteristics but also they must be safe and comfortable in use. In this connection, the development of fuel cells (FC) in which chemical energy is directly converted into electrical one becomes most topical. Especially, direct borohydride fuel cells (DBFCs) are intensively evolved in which alkaline aqueous solutions of such salts as $\mathrm{LiBH}_{4}, \mathrm{NaBH}_{4}$, and $\mathrm{KBH}_{4}$ are used as fuel [3-9]. In these systems, electrical energy is generated by means of hydrolysis and electrochemical oxidation of borohydrides into borates. In alkaline media, these are $\mathrm{LiBO}_{2}, \mathrm{NaBO}_{2}$, and $\mathrm{KBO}_{2}[10-12]$ whose solubility essentially influences the power characteristics of FC [13-15]. The difficulty of the design of effective and sustainable anode electrocatalysts for the anodic oxidation of borohydride limits the efficiency and power density attainable in these devices [16-18].

The fuel of DBFCs is a multiple mixture whose specific characteristics directly depend on the ratio of its components
$\mathrm{BH}_{4}^{-} / \mathrm{OH}^{-} / \mathrm{H}_{2} \mathrm{O}$ [19-24]. It can be an aqueous solution of $\mathrm{NaOH}$ and $\mathrm{NaBH}_{4}$ in the initial state and an aqueous solution of $\mathrm{NaOH}, \mathrm{NaBH}_{4}$, and $\mathrm{NaBO}_{2}$ in the discharged (partially or fully) state. Besides, the fuel composition is changed due to side reaction; it can dry up or water out, and it also can be acidified and/or carbonated by chemical interaction with carbon dioxide from air. In this case, additional components will appear in the solution, such as carbonate $\mathrm{Na}_{2} \mathrm{CO}_{3}$ and bicarbonate $\mathrm{NaHCO}_{3}$ at deeper carbonization in accordance with the ionic reactions:

I stage (carbonate formation)

$$
2 \mathrm{OH}^{-}+\mathrm{CO}_{2}=\mathrm{CO}_{3}{ }^{2-}+\mathrm{H}_{2} \mathrm{O}
$$

II stage (bicarbonate formation)

$$
\mathrm{CO}_{3}{ }^{2-}+\mathrm{CO}_{2}+\mathrm{H}_{2} \mathrm{O}=2 \mathrm{HCO}_{3}^{-}
$$

These side reactions have high significance for the proper functioning of FC, since the salts $\mathrm{Na}_{2} \mathrm{CO}_{3}$ and $\mathrm{NaHCO}_{3}$ (as well as the corresponding lithium and potassium salts) poorly dissolve in aqueous alkaline solutions. These salts and their 
crystal hydrates are deposited in the porous structure of the electrodes to deteriorate them. So it is important, on the one hand, to preserve the fuel from contact with $\mathrm{CO}_{2}$ and, on the other hand, to control the carbonate concentration in it.

In this connection, for the development and maintenance of FCs, regular monitoring of the chemical composition of the fuel used is necessary. It requires control of the concentration of each dissolved component during the working process of FC, determination of the discharge degree of the fuel, and evaluation of the conformity of the current state of the fuel mixture to its theoretical composition calculated from material balance.

Earlier, a number of methods were proposed for quantitative determination of the total boron and boron compounds in analyzed samples [25-31]. To analyze borates and boric acid, the titrimetric [28-31], photometric [32], and fluorescent methods [33-35] have been suggested. It is also possible to carry out the selective determination of borohydrides by the hydrogen volumetric method [36, 37], titration [38-41] with permanganate [36], hypochlorite [42], iodate [10, 43], and the voltammetric [44-46] or potentiometric [47-49] titration methods. Titration of borohydride solutions with acid, in particular, $\mathrm{HCl}$, was suggested in a few papers [36, $40,50]$, where the reaction equation was written as

$$
\mathrm{NaBH}_{4}+\mathrm{HCl}+3 \mathrm{H}_{2} \mathrm{O}=4 \mathrm{H}_{2}+\mathrm{H}_{3} \mathrm{BO}_{3}+\mathrm{NaCl}
$$

In the case of potentiometric acid titration of aqueous $\mathrm{NaBH}_{4}$ solutions, it is pointed [36] that actually it is sodium borate formed as a result of $\mathrm{NaBH}_{4}$ hydrolysis which is titrated:

$$
\mathrm{BO}_{2}{ }^{-}+\mathrm{H}_{3} \mathrm{O}^{+}=\mathrm{H}_{3} \mathrm{BO}_{3}
$$

Thus, there is no unified method of quantitative analysis of boron-containing compounds and other anions presented in the fuel solution of DBFC. For selective determination of each component, it is necessary to consecutively apply several techniques. In the present paper, we have developed a methodology for quantitative analysis of complex "borohydride-borate-alkali-carbonate-water" mixtures based on the methods of acid-base and iodometric titration. The first method allows simultaneous estimation of the contents of hydroxide, carbonate, and the "borate + borohydride" total with their joint presence in the sample. The second method allows selective determining the borohydride content.

\section{Experimental Section}

The contents of hydroxide ions, carbonate ions, and total borate and borohydride ions were determined by the acidbase titration method with a $0.1 \mathrm{~mol} \cdot \mathrm{L}^{-1} \mathrm{HCl}$ solution as the titrant. A fuel sample taken from FC for analysis is a highly alkaline medium. For acid-base titration, it was repeatedly diluted. A sample of a certain weight $(0.1$ to $0.5 \mathrm{~g})$ was taken from the fuel analyzed, quantitatively transferred to a $250 \mathrm{~mL}$ glass for titration, and brought to $100.0 \mathrm{~mL}$ with distilled water. A homogeneous solution with $\mathrm{pH} \approx 11-13$ resulted. The analysis result was then recalculated in terms of the initial fuel in view of the dilution factor. A fixed initial volume of the titratable mixture $V_{0}=100.0 \mathrm{~mL}$ is required to further correct modeling of the titration curve. Titration was started from some initial $\mathrm{pH}$ value and ended at $\mathrm{pH} \approx 2-3$. The positions of peaks were defined, and both titration curves (integral and differential) were saved in a data file for subsequent computer simulation. To analyze borohydride ions, the iodometric redox titration method was used. The analogous sample of the analyzed fuel (0.1 to $0.5 \mathrm{~g}$ ) was quantitatively transferred into a $50 \mathrm{~mL}$ flask and brought to the mark with a $1 \mathrm{~mol} \cdot \mathrm{L}^{-1} \mathrm{NaOH}$ solution. Then, a $5 \mathrm{~mL}$ aliquot was sampled, transferred to a glass for titration, and brought to $50 \mathrm{~mL}$ with a $1 \mathrm{~mol} \cdot \mathrm{L}^{-1} \mathrm{NaOH}$ or $\mathrm{KOH}$ solution with further titration with a $0.1 \mathrm{~mol} \cdot \mathrm{L}^{-1}$ standard iodine solution up to a preset potential value. An automatic ATP-02 titrator ("Aquilon", Russia) was applied. The software package of the titrator provides titration up to a preset electrode potential value or $\mathrm{pH}$ at an automatically changed rate of the titrant. A glass indicator electrode and a silver-chloride reference electrode were used for acid-base titration; a platinum indicator electrode and a glass reference electrode were applied for iodometric titration. All analyses were carried out under thermostating at $25^{\circ} \mathrm{C}$.

Chemically pure reagents (reagent grade) were used to prepare reference solutions of a desired composition for checking our analytical methodology. The chemicals used were $\mathrm{NaBO}_{2} \cdot 4 \mathrm{H}_{2} \mathrm{O}$ (Vecton Corp, Russia, the analytical reagent content $\left.w_{\mathrm{NaBO}_{2}}=0.490 \pm 0.003\right) ; \mathrm{KBO}_{2} \cdot 1.25 \mathrm{H}_{2} \mathrm{O}$ (Vecton Corp, the reagent content $w_{\mathrm{KBO}_{2}}=0.767 \pm 0.001$ ), $\mathrm{NaOH} \cdot x \mathrm{H}_{2} \mathrm{O}$ (Ecros Corp., Russia, the reagent content $w_{\mathrm{NaOH}}=0.989 \pm 0.002$; water content $w_{\mathrm{H}_{2} \mathrm{O}}=0.01 \pm$ 0.003 ), $\mathrm{KOH} \cdot x \mathrm{H}_{2} \mathrm{O}$ (Ecros Corp., the reagent content $w_{\mathrm{KOH}}=0.898 \pm 0.003$; water content $w_{\mathrm{H}_{2} \mathrm{O}}=0.101 \pm$ 0.003), $\mathrm{NaBH}_{4}$ (Aviabor Corp, Russia, the reagent content $w_{\mathrm{NaBH}_{4}}=0.974 \pm 0.005$ ), $\mathrm{KBH}_{4}$ (Aviabor Corp., the reagent content $\left.w_{\mathrm{KBH}_{4}}=0.971 \pm 0.006\right)$, and distilled water without dissolved carbon dioxide. Every reagent had undergone common chemical analysis to analyze the basic substance, water content, and carbonate content. No analytically detectable carbonate impurity in the solid reagents was found. The exact composition of the solid-state reagents was taken into consideration at preparing reference solutions. The error of each controlled concentration of the reference solutions can be estimated less than $1.5 \%$.

\section{Results and Discussion}

3.1. Determination of Borohydride, Borate, Hydroxide, and Carbonate by Acid-Based Titration. The analyzed object was an aqueous solution containing a mixture of anions $\mathrm{OH}^{-}+$ $\mathrm{BO}_{2}{ }^{-}+\mathrm{BH}_{4}{ }^{-}+\mathrm{CO}_{3}{ }^{2-}$ in a random ratio as highly soluble sodium and potassium salts. During the titration process by an aqueous solution of acid, the following reactions proceed:

$$
\begin{gathered}
\mathrm{OH}^{-}+\mathrm{H}^{+}=\mathrm{H}_{2} \mathrm{O} \\
\mathrm{BH}_{4}{ }^{-}+2 \mathrm{H}_{2} \mathrm{O} \stackrel{\mathrm{H}^{+}}{\longrightarrow} \mathrm{BO}_{2}{ }^{-}+4 \mathrm{H}_{2} \uparrow
\end{gathered}
$$




$$
\begin{gathered}
\mathrm{BO}_{2}{ }^{-}+\mathrm{H}^{+}=\mathrm{HBO}_{2} \\
\mathrm{CO}_{3}{ }^{2-}+\mathrm{H}^{+}=\mathrm{HCO}_{3}{ }^{-} \\
\mathrm{HCO}_{3}{ }^{-}+\mathrm{H}^{+}=\mathrm{H}_{2} \mathrm{CO}_{3}
\end{gathered}
$$

In the presence of $\mathrm{BH}_{4}{ }^{-}$, the first stage is the irreversible hydrolysis of $\mathrm{BH}_{4}{ }^{-}$catalyzed with acid which is not consumed. Protons are consumed at the second stage only (reaction (9)). As a result, the total boron $\left(\mathrm{BO}_{2}{ }^{-}+\mathrm{BH}_{4}{ }^{-}\right)$is titrated out at the acid-base titration.

Reactions (5)-(9) proceed concurrently. The predomination of this or that reaction is determined by the ratio of the corresponding dissociation constants of $\mathrm{HBO}_{2}, \mathrm{H}_{2} \mathrm{CO}_{3}$, and water $\mathrm{H}_{2} \mathrm{O}$. This predomination changes as the titration curve goes with gradual change of $\mathrm{pH}$ from the initial $\mathrm{pH}$ value $\approx$ $11-13$ to the final one $\approx 2-3$. The values of the dissociation constants are such $[51,52]$ that at the addition of acid, the first reactions (5) and (6) occur, then the reactions (7) and (8) proceed, and the titration process is completed with reaction (9). It should be noted that the reaction (7) is written in a simplified form, as it is known about the existence of a number of borate anion forms but the final product of protolysis is orthoboric acid $\mathrm{H}_{3} \mathrm{BO}_{3}$. This may be ignored within our $\mathrm{pH}$ range.

Borohydride hydrolysis reaction (6) takes place in aqueous alkaline solutions even at high $\mathrm{pH}$ but its rate is extremely low [21]. Table 1 comprises approximate rates of $\mathrm{BH}_{4}{ }^{-}$decomposition due to hydrolysis at $25^{\circ} \mathrm{C}$. One can see that the hydrolysis of $\mathrm{BH}_{4}{ }^{-}$slowly proceeds at $\mathrm{pH} \approx 11-13$ in the solutions at acid-base titration, but this hydrolysis is part of the analytical procedure. Hydrolysis is sharply accelerated at $\mathrm{pH} \approx 7-9$ and the borate ions formed are further bound in reaction (7). No complex mechanism of the protolysis of $\mathrm{BH}_{4}{ }^{-}$ions $[8,21,34]$ is reflected on the titration curve $\mathrm{pH}$ versus $V_{t}$.

Let us assume that the initial aqueous solution has a volume $V_{0}$, containing $n_{\mathrm{OH}^{-}}$of alkali, $n_{\mathrm{BH}_{4}}{ }^{-}$of borohydride,

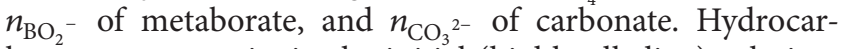
bonate cannot exist in the initial (highly alkaline) solution; that is, $n_{\mathrm{HCO}_{3}{ }^{-}}=0$. The formation and consumption of very small amounts of water during the neutralization reaction are neglected but the dilution degree of the initial mixture titrant is taken into account. The titrant $(t)$ is an aqueous $\mathrm{HCl}$ solution with a concentration $N_{t}$ to be added into the mixture at the current time in the amount $V_{t} \mathrm{~mL}$. Then, taking into account the titrant-caused dilution, the overall molar concentrations $C_{i}$ are

$$
\begin{gathered}
C_{t}=\frac{N_{t} V_{t}}{V}, \\
C_{\mathrm{alc}}=\frac{n_{\mathrm{OH}^{-}}}{V} ; \quad C_{B}=\frac{n_{\mathrm{BH}_{4}^{-}}+n_{\mathrm{BO}_{2}}^{-}}{V} ; \quad C_{\mathrm{carb}}=\frac{n_{\mathrm{CO}_{3}{ }^{2-}}^{V} .}{V} .
\end{gathered}
$$

Here $V=V_{0}+V_{t}$ is the total volume of the mixture at the current instant of titration. Unlike the overall concentrations $C_{i}$, the current equilibrium values of the molar concentrations $\left[\mathrm{H}^{+}\right],\left[\mathrm{OH}^{-}\right],\left[\mathrm{BH}_{4}{ }^{-}\right],\left[\mathrm{BO}_{2}{ }^{-}\right],\left[\mathrm{CO}_{3}{ }^{2-}\right],\left[\mathrm{HCO}_{3}{ }^{-}\right],\left[\mathrm{HBO}_{2}\right]$,
TABLE 1: Approximate rates of borohydride ion $\mathrm{BH}_{4}{ }^{-}$decomposition due to hydrolysis at $25^{\circ} \mathrm{C}$.

\begin{tabular}{lc}
\hline Concentration $\left[\mathrm{OH}^{-}\right]$or $\mathrm{pH}$ & Initial rate of $\mathrm{BH}_{4}{ }^{-}$decomposition \\
\hline $2.33 \mathrm{~mol} \cdot \mathrm{L}^{-1}$ & $<0.1 \% \cdot \mathrm{day}^{-1}$ \\
$\mathrm{pH}=13$ & $\approx 1.5 \% \cdot \mathrm{day}^{-1}$ \\
$\mathrm{pH}=11$ & $\approx 7 \% \cdot \mathrm{hr}^{-1}$ \\
$\mathrm{pH}=9$ & $\approx 0.2 \% \cdot \mathrm{s}^{-1}$ \\
$\mathrm{pH}=7$ & $>10 \% \cdot \mathrm{s}^{-1}$ \\
\hline
\end{tabular}

and $\left[\mathrm{H}_{2} \mathrm{CO}_{3}\right]$ are marked with symbols in square brackets and they are calculated from the equilibrium constants of the titration reactions.

An additional correction is taken into account for the average ionic activity coefficient. We used the 2nd approximation of Debye-Huckel's theory as Gyuntelberg's equation where the activity coefficient is only determined by the ionic strength of the solution and the squared ion charges [53]. Then, $f$ is the activity coefficient of all single-charged ions, but in the equations containing the double-charged carbonate ion concentration, the factor $f^{4}$ will appear. Gyuntelberg's equation at $25^{\circ} \mathrm{C}$ looks like

$$
\lg f=-0.5092 \frac{\sqrt{I}}{1+\sqrt{I}}
$$

where $I=0.5 \sum_{i} c_{i} z_{i}^{2}$ is the ionic strength of the solution calculated by the formula in our case:

$$
\begin{aligned}
I=0.5 \times\left\{C_{t}+C_{\text {alc }}+C_{B}+2 \times C_{\text {carb }}\right. \\
+\left[\mathrm{H}^{+}\right]+\left[\mathrm{OH}^{-}\right]+\left[\mathrm{BH}_{4}^{-}\right]+\left[\mathrm{BO}_{2}{ }^{-}\right] \\
\left.+\left[\mathrm{HCO}_{3}^{-}\right]+4 \times\left[\mathrm{CO}_{3}^{2-}\right]\right\}
\end{aligned}
$$

Gyuntelberg's equation has an advantage over other approximations of having no arbitrary parameters and describing well electrolyte solutions when $I \approx 0.1$, which is the case in our acid-base titration (the concentration of any ions in solution at different stages of titration did not exceed $\left.0.1 \mathrm{~mol} \cdot \mathrm{L}^{-1}\right)$. The concentration of solutions was chosen so as not to blur steps on the titration curve and, at the same time, the correction to the activity coefficients should be small.

As a result, with the experimental data arrays $V_{t}, \mathrm{pH}$, $d \mathrm{pH} / d V_{t}$, and using (10) and (11), we obtain the data arrays $C_{t}, C_{B}, C_{\mathrm{alc}}$, and $C_{\text {carb }}$. The current values of the equilibrium concentrations at every titration point can be calculated from the conditions of chemical equilibrium and material balance by means of the appropriate formulae:

$$
\begin{gathered}
{\left[\mathrm{OH}^{-}\right]=\frac{K_{W}}{f^{2}\left[\mathrm{H}^{+}\right]} ;} \\
{\left[\mathrm{BH}_{4}{ }^{-}\right]+\left[\mathrm{BO}_{2}{ }^{-}\right]=\frac{C_{B}}{1+f^{2}\left[\mathrm{H}^{+}\right] / K_{B}} ;} \\
{\left[\mathrm{CO}_{3}{ }^{2-}\right]=\frac{C_{\mathrm{carb}}}{1+\left(f^{4}\left[\mathrm{H}^{+}\right] / K_{2}\right)\left(1+f^{2}\left[\mathrm{H}^{+}\right] / K_{1}\right)} ;}
\end{gathered}
$$




$$
\begin{gathered}
{\left[\mathrm{HCO}_{3}{ }^{-}\right]=\frac{C_{\mathrm{carb}}}{1+f^{2}\left[\mathrm{H}^{+}\right] / K_{1}+K_{2} / f^{4}\left[\mathrm{H}^{+}\right]}} \\
{\left[\mathrm{H}_{2} \mathrm{CO}_{3}\right]=\frac{C_{\mathrm{carb}}}{1+\left(K_{1} / f^{2}\left[\mathrm{H}^{+}\right]\right)\left(1+K_{2} / f^{4}\left[\mathrm{H}^{+}\right]\right)}}
\end{gathered}
$$

where

$$
\left[\mathrm{H}^{+}\right]=f^{-1} 10^{-\mathrm{pH}} \text {. }
$$

Here the ionic product of water (autoprotolysis constant) is $K_{W}=f^{2}[\mathrm{OH}] \cdot[\mathrm{H}]=1 \times 10^{-14}$ at $25^{\circ} \mathrm{C}[52]$; the dissociation constant of metaboric acid $\mathrm{HBO}_{2}$ is $K_{\mathrm{B}}=$ $f^{2}\left(\left(\left[\mathrm{BO}_{2}\right] \cdot[\mathrm{H}]\right) /\left[\mathrm{HBO}_{2}\right]\right)$; the dissociation constant of carbonic acid $\mathrm{H}_{2} \mathrm{CO}_{3}$ at the first stage is $K_{1}=f^{2}\left(\left(\left[\mathrm{HCO}_{3}\right]\right.\right.$. $\left.[\mathrm{H}]) /\left[\mathrm{H}_{2} \mathrm{CO}_{3}\right]\right)=4.45 \times 10^{-7}$ at $25^{\circ} \mathrm{C}$ [52]; the dissociation constant of carbonic acid $\mathrm{H}_{2} \mathrm{CO}_{3}$ at the second stage is $K_{2}=$ $f^{4}\left(\left(\left[\mathrm{CO}_{3}\right] \cdot[\mathrm{H}]\right) /\left[\mathrm{HCO}_{3}\right]\right)=4.69 \times 10^{-11}$ at $25^{\circ} \mathrm{C}[52]$. Moreover, processing the titration curves of simple solutions of a fixed composition (e.g., $0.01 \mathrm{~mol} \cdot \mathrm{L}^{-1} \mathrm{NaBO}_{2}$ ) can be used for refinement of these dissociation constants.

Let us determine the calculated volume $V_{\text {calc }}$ of the titrant from the material balance by acid, by boron, and by carbon, only considering the acid consumption by the titration reactions (5), (7)-(9). The material balance equation is thus written as

$$
\begin{aligned}
C_{t}= & {\left[\mathrm{H}^{+}\right]+\left(C_{\mathrm{alc}}-\left[\mathrm{OH}^{-}\right]\right) } \\
& +\left[\mathrm{HBO}_{2}\right]+\left[\mathrm{HCO}_{3}^{-}\right]+2 \times\left[\mathrm{H}_{2} \mathrm{CO}_{3}\right],
\end{aligned}
$$

(the initial content of acid in an alkaline solution $\left[\mathrm{H}^{+}\right]^{0}<$ $10^{-11} \mathrm{~mol} \cdot \mathrm{L}^{-1}$ is ignored).

The calculated value of $V_{\text {calc }}$ is estimated from the current $\mathrm{pH}$ value and (10) and (15). As a result, the calculated points of the titration curve of solutions containing a mixture of anions $\mathrm{OH}^{-}, \mathrm{BH}_{4}{ }^{-}, \mathrm{BO}_{2}{ }^{-}$, and $\mathrm{CO}_{3}{ }^{2-}$ are determined by the equation

$$
\begin{aligned}
& V_{\text {calc }}=\frac{V}{N_{\mathrm{HCl}}}( {\left[\mathrm{H}^{+}\right]+\mathrm{C}_{\mathrm{alc}}-\left[\mathrm{OH}^{-}\right]+\mathrm{C}_{B}-\left[\mathrm{BH}_{4}^{-}\right] } \\
&\left.-\left[\mathrm{BO}_{2}^{-}\right]+\left[\mathrm{HCO}_{3}^{-}\right]+2 \times\left[\mathrm{H}_{2} \mathrm{CO}_{3}\right]\right),
\end{aligned}
$$

where the current equilibrium values of molar concentrations are determined by (14) and (15). Equation (17) is very convenient for computer simulations. It allows calculating the $\mathrm{pH}-V_{\text {calc }}$ dependence and plotting the whole calculated titration curve. By means of fitting the calculated curve to the experimental curve, we find the amounts of components in

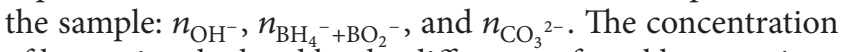
of borate is calculated by the difference of total boron minus

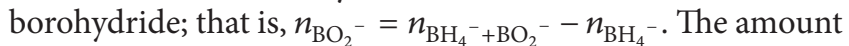
of borohydride in the mixture is selectively determined by iodometric titration.

3.2. Determination of Borohydride in Solution by Iodometric Titration. As shown in [39], the quantification of $\mathrm{BH}_{4}{ }^{-}$ in solution by direct iodometric titration is based on the reaction proceeding quantitatively in an alkaline medium:

$$
4 \mathrm{I}_{2}+\mathrm{BH}_{4}^{-}+8 \mathrm{OH}^{-}=\mathrm{BO}_{2}^{-}+8 \mathrm{I}^{-}+6 \mathrm{H}_{2} \mathrm{O}
$$

Usually, the direct titration is made in a low alkaline medium $(\mathrm{pH}<11)$ because iodine interacts with hydroxide ions to form nonactive iodate ion $\mathrm{IO}_{3}{ }^{-}$in higher alkaline solution [34]:

$$
3 \mathrm{I}_{2}+6 \mathrm{OH}^{-} \longrightarrow \mathrm{IO}_{3}^{-}+5 \mathrm{I}^{-}+3 \mathrm{H}_{2} \mathrm{O}
$$

However, borohydride ions are insufficiently stable at room temperature when $\mathrm{pH}<11$. Table 1 comprises approximate rates of $\mathrm{BH}_{4}{ }^{-}$decomposition due to hydrolysis. One can see that the fuel with alkalinity above $2 \mathrm{~mol} \cdot \mathrm{L}^{-1}$ is almost not subjected to hydrolysis at $25^{\circ} \mathrm{C}$. The same applies to the iodometric redox titration method used by us, which requires a $1 \mathrm{~mol} \cdot \mathrm{L}^{-1} \mathrm{NaOH}$ solution. In a $1 \mathrm{~mol} \cdot \mathrm{L}^{-1}$ alkaline solution, the addition of iodine to borohydride is also accompanied by extremely slight hydrogen release as a result of borohydride decomposition. Under these conditions, about $0.5-1 \%$ of $\mathrm{BH}_{4}{ }^{-}$ions is decomposed, while a negligible amount of iodate is formed by reaction (18) with iodine consumption of $\sim 0.5-1 \%$. Thus, any mistakes are compensated and direct iodometric titration allows one to obtain the result closest to the true value of borohydride concentration (the error not to exceed $0.05 \%$ ).

\subsection{Processing Titration Curves and Estimation of Accuracy.} The titration curves $\mathrm{pH}$ versus $V_{t}$ and the appropriate dependences $d \mathrm{pH} / d V_{t}$ versus $V_{t}$ obtained by acid-base titration of aqueous solutions of various anion mixtures are shown in Figure 1 and the analogous curves obtained by iodometric titration are shown in Figure 2. The first distinct step presented (not always) on the iodometric titration curve reflects a complex mechanism of the chemical reaction (18) and is neglected. The determination of the amount of the titrant is carried out by the second sharp leap within the potential range 0 to $600 \mathrm{mV}$ (Figure 2).

The titration curves were processed by two ways, namely, a simple method of differentiation and a more complex method of computer simulations. For the iodometric determination of borohydride it is enough to use the method of differentiation only, while for acid-base titration, the best results are obtained when both methods (differentiation and simulation) are used.

The method of differentiation is based on the equivalence points coinciding with the inflections on the $\mathrm{pH}$ versus $V_{t}$ curve and with appropriate maxima on the differential $d \mathrm{pH} / d V_{t}$ versus $V_{t}$ curve (Figure 1 ). The positions of the maximum points $V_{t}^{*}$ are fixed, the titrant volume consumed for titration of the $i$ th component $\Delta V_{t}^{*}=V_{t, i}^{*}-V_{t, i-1}^{*}$ is measured, and the amount of each component is calculated. However, in few complex cases, it is possible to state that an extreme point on the differential $d^{2} \mathrm{pH} / d\left(V_{t}\right)^{2}=0$ curve is close to an equivalence point at sharp changes of $\mathrm{pH}$. If smoothed inflections with a small $\mathrm{pH}$ difference are observed or two points of inflection are near each other, a significant systematic error arises.

The method of simulation is based on the theory explained above. The program for calculating titration curves uses the appropriate theoretical equations (10)-(17) and combines the experimental $\mathrm{pH}$ versus $V_{t}$ curve with the calculated 


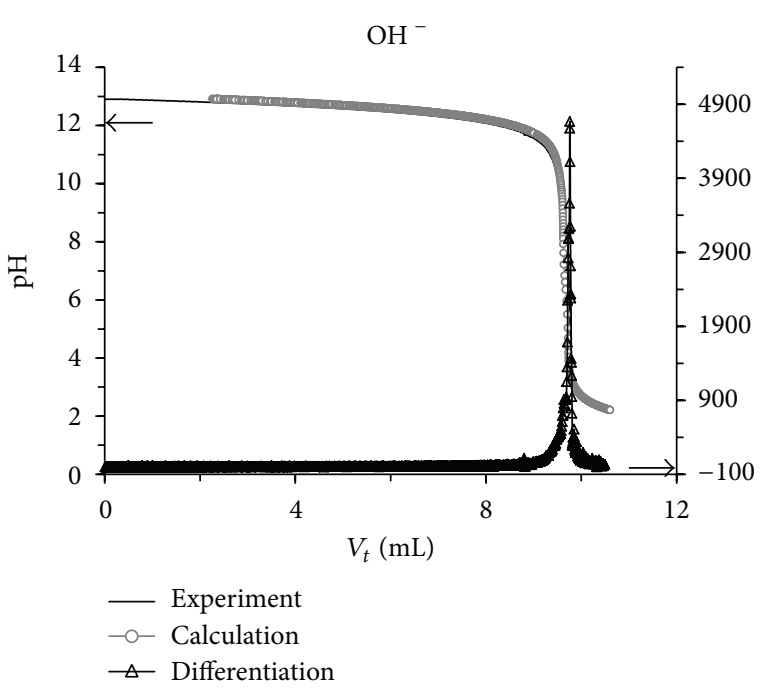

(a)

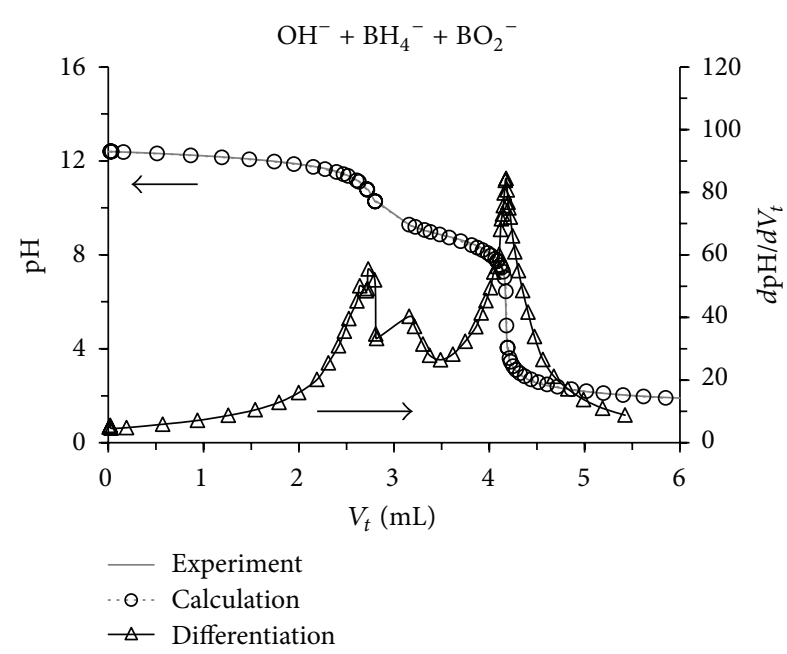

(c)

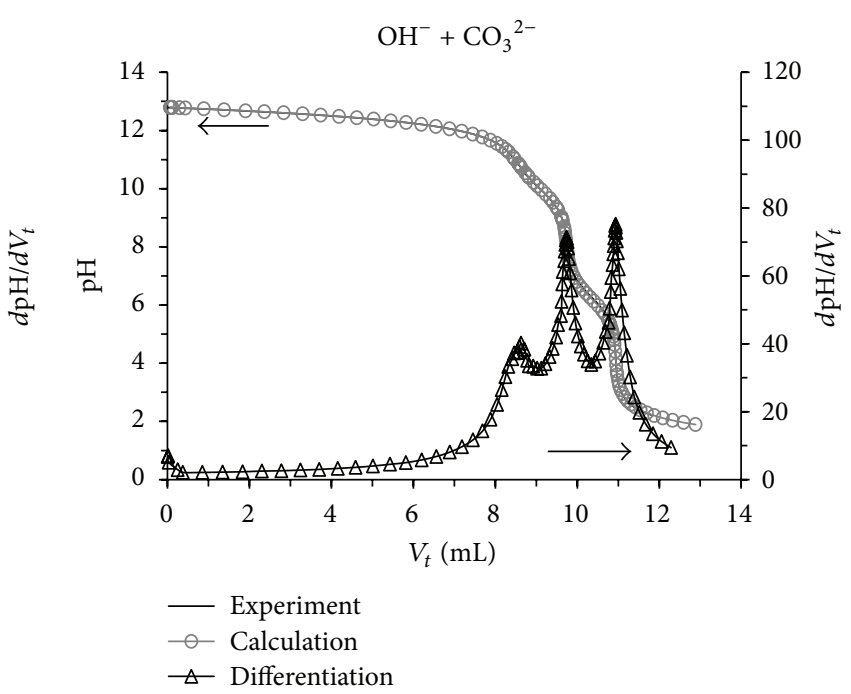

(b)

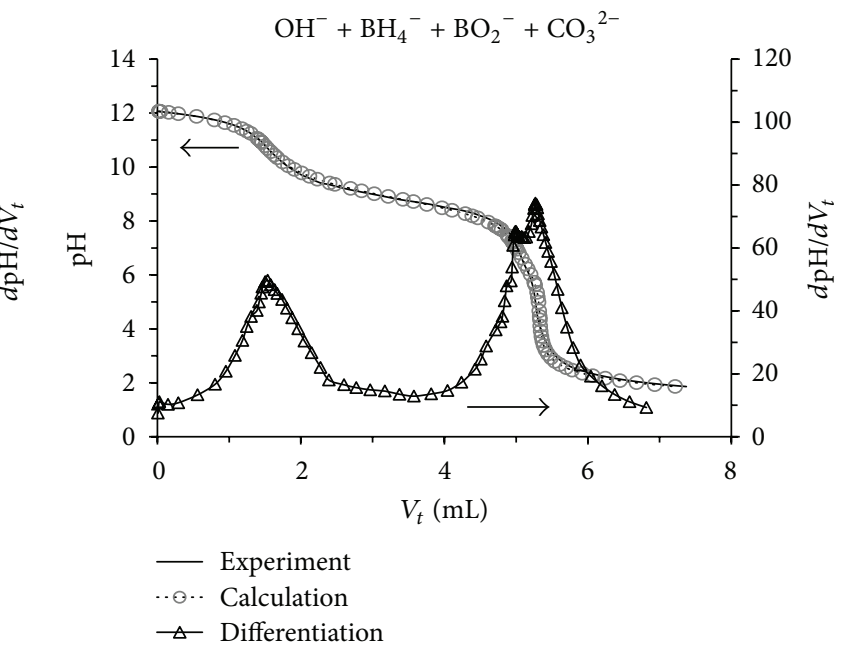

(d)

FIGURE 1: Calculated titration curves, experimental titration curves, and the corresponding $d \mathrm{pH} / d V_{t}$ versus $V_{t}$ curves for aqueous solutions of several mixtures of anions: (a): $\mathrm{OH}^{-}$; (b): $\mathrm{OH}^{-}+\mathrm{CO}_{3}{ }^{2-}$; (c): $\mathrm{OH}^{-}+\mathrm{BH}_{4}^{-}$or $\mathrm{OH}^{-}+\mathrm{BO}_{2}{ }^{-}$or $\mathrm{OH}^{-}+\mathrm{BH}_{4}^{-}+\mathrm{BO}_{2}^{-} ;(\mathrm{d}): \mathrm{OH}^{-}+\mathrm{BH}_{4}^{-}+$ $\mathrm{BO}_{2}{ }^{-}+\mathrm{CO}_{3}^{-}$.

$\mathrm{pH}$ versus $V_{\text {calc }}$ one. The variable parameters are the sought

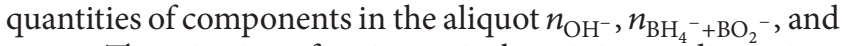
$n_{\mathrm{CO}_{3}}{ }^{2-}$. The criterion of optimum is the minimum dispersion:

$$
\begin{aligned}
S^{2} & =\frac{\sum_{k=1}^{K}\left(\mathrm{pH}_{k}-\mathrm{pH}_{\mathrm{calc}, k}\right)^{2}}{K-1} \\
& =\frac{\sum_{k=1}^{K}\left(\left(d \mathrm{pH} / d V_{t, k}\right)\left(V_{t, k}-V_{\mathrm{calc}, k}\right)\right)^{2}}{K-1} .
\end{aligned}
$$

Here $K$ is the number of points on the titration curve. Figure 1 shows the experimental and calculated titration curves for few solutions of various multicomponent mixtures. It is visible that the applied computational methods allow exact simulating experimental curves.

Error Analysis and Estimation of Accuracy. A number of reference solutions of a desired composition were prepared using $\mathrm{KBO}_{2}, \mathrm{NaBH}_{4}, \mathrm{KBH}_{4}, \mathrm{NaOH}, \mathrm{KOH}, \mathrm{Na}_{2} \mathrm{CO}_{3}$, and $\mathrm{K}_{2} \mathrm{CO}_{3}$ for validation of our analytical methodology (the concentration ranges of each analyzed ion in the considered samples are presented in Table 2). In order to detect systematic errors, the dependences of the "measured/weighted" ratios on the anionic fraction $\omega_{i}$ were plotted $\left(\omega_{i}\right.$ is the mole fraction of the $i$ th anion in the total amount of the analyzed anions; $\omega$ varies from 0 up to 1 ). The results are given in Figure 3. The average value of the "measured/weighted" ratio for each ion is presented in Table 3. 
TABLE 2: Considered concentration ranges of analyzed ions in the sample.

\begin{tabular}{lc}
\hline Ion & Concentration range in the analyzed sample, $\mathrm{mol} \cdot \mathrm{L}^{-1}$ \\
\hline $\mathrm{OH}^{-}$ & $0.02-1.2$ \\
$\mathrm{BH}_{4}{ }^{-}$ & $0.02-0.2$ \\
$\mathrm{BO}_{2}{ }^{-}$ & $0.05-0.2$ \\
$\mathrm{CO}_{3}{ }^{2-}$ & $0.008-0.1$ \\
\hline
\end{tabular}

It is apparent from Table 3 that the simulation method also gives a systematic error. The causes can be simplification of the theory, the impossibility to consider all side processes, the inability to exactly calculate activity coefficients, and so forth, so the shape of the calculated curve may not completely coincide with the experimental curve. In particular, in the titration process of borate solutions, the formation of poliborates and their hydrated forms is possible. In the case of simulation, the lower branch of the titration curve should be limited when all equivalence points are passed over. Accelerated titration or cold solution may cause an additional error due to the inhibition of reaction (6) and the failure of chemical equilibrium.

The concentration of $\mathrm{OH}^{-}$ions is estimated with an accuracy of 0.959 and 0.956 for the differentiation and simulation methods, respectively. The total of $\left(\mathrm{BH}_{4}{ }^{-}+\mathrm{BO}_{2}{ }^{-}\right)$is estimated with an accuracy of 1.023 and 1.012 for the differentiation and simulation methods, respectively (Table 3 ). Thus, for the $\mathrm{OH}^{-}+\mathrm{BH}_{4}{ }^{-}+\mathrm{BO}_{2}{ }^{-}$system, the differentiation and simulation methods give similar results and have no advantages over each other, and the systematic error is small but naturally increases with decreasing share of the analyzed ion. The trend of the systematic error is shown in Figure 3(a) by means of solid lines. Both methods overestimate the content of boron in the sample and underestimate the content of alkali. For compensation of the systematic error, the following equations have been obtained for the method of differentiation:

$$
\begin{gathered}
\beta_{\mathrm{OH}^{-}}=\left[1.38-0.4 \omega_{\mathrm{OH}^{-}}^{-0.05}\right]^{-1} ; \\
\beta_{\left(\mathrm{BH}_{4}{ }^{-}+\mathrm{BO}_{2}^{-}\right)}=\left[\omega_{\mathrm{BH}_{4}^{-}+\mathrm{BO}_{2}^{-}}^{-0.05} 0.025\right]^{-1}
\end{gathered}
$$

and for the method of simulation:

$$
\begin{gathered}
\beta_{\mathrm{OH}^{-}}=\left[1.39-0.4 \omega_{\mathrm{OH}^{-}}^{-0.08}\right]^{-1} ; \\
\beta_{\left(\mathrm{BH}_{4}{ }^{-}+\mathrm{BO}_{2}{ }^{-}\right)}=\left[0.7 \omega_{\mathrm{BH}_{4}{ }^{-}+\mathrm{BO}_{2}{ }^{-}}^{-0.05}+0.28\right]^{-1} .
\end{gathered}
$$

After analysis and the determination of the components

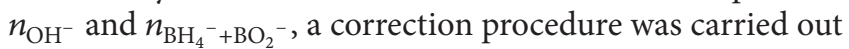
by multiplying the values $n_{i}$ found by the corresponding correction coefficients $\beta_{i}$, calculated from formulae (21) or (22). Finally, the corrected amounts of the $i$ th component in the sample $n_{i, \text { cor }}$ are

$$
n_{i, \mathrm{cor}}=\beta_{i} n_{i}
$$

Figure 3(b) shows the result of correction of the data given in Figure 3(a). The systematic error was totally compensated for all the variants of analysis (Table 3).

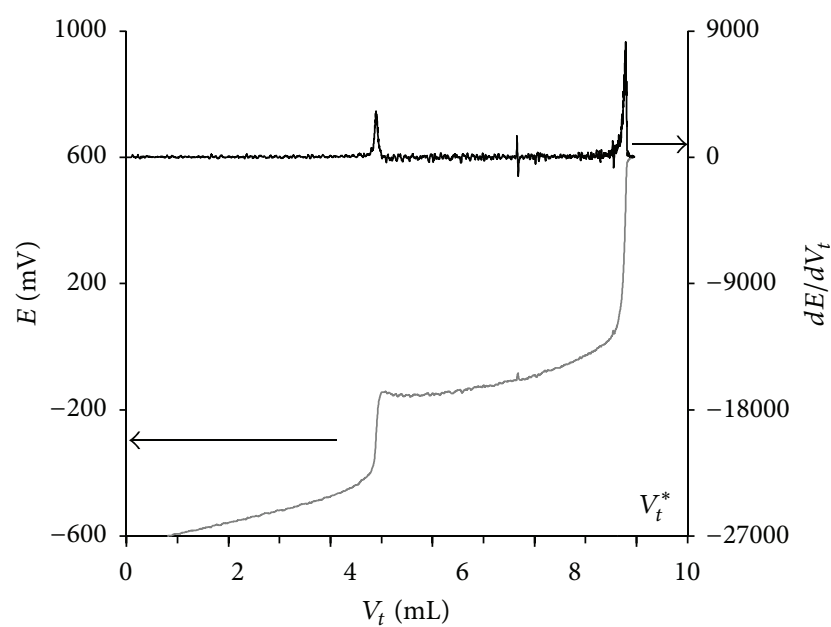

FIGURE 2: Curve of direct iodometric titration of borohydride ions in an aqueous solution with the mixture of anions $\mathrm{OH}^{-}+\mathrm{BH}_{4}^{-}+$ $\mathrm{BO}_{2}{ }^{-}+\mathrm{CO}_{3}{ }^{2-}\left(V_{t}^{*}\right.$ is equivalence point $)$.

When the value of the anionic fraction $0.4<\omega_{i}<1$, all points lie within the "measured/weighted" range 0.95-1.05; that is, the random error does not exceed 5\%; all points lie within the range $0.88-1.12$ when $0.05<\omega_{i}<0.4$; that is, the random error does not exceed $12 \%$. It is only possible to perform semiquantitative analysis of any component at its very small content in the mixture $\left(\omega_{i}<0.02\right)$. On correction, the average accuracy parameter of the $\mathrm{OH}^{-}$concentration is 1.000 for differentiation and 1.001 for simulation and the average accuracy parameter for the $\left(\mathrm{BH}_{4}{ }^{-}+\mathrm{BO}_{2}{ }^{-}\right)$total is 1.008 for differentiation and 1.004 for simulation (Table 3 ).

The feature of titration of alkaline-carbonate solutions is the existence of three leaps on the titration curve (Figure 1(b)). The first leap belongs to alkali, while the second and third ones are due to carbonates. Correspondingly, when the quantities of components are determined by the location of peaks on the differential curve, the quantity of $\mathrm{CO}_{3}{ }^{2-}$ is included twice. The analysis of carbonate by means of the second peak gives a worse result than by the third one. At a very small content of carbonate, the second peak is not detected. The average "measured/weighted" value is 1.215 for $\mathrm{CO}_{3}{ }^{2-}$ ions by the second peak on the differential curve and 1.115 in the case of the third peak and the "measured/weighted" value is 1.089 for the method of simulation. The results of control determination of the alkali and carbonate contents in the reference solutions $\mathrm{OH}^{-}+\mathrm{CO}_{3}{ }^{2-}$ are shown in Figures 3(c) and 3(d) for the two methods as the dependence of the accuracy parameter on the anionic fractions $\omega_{i}$. In all cases, the points of differentiation are more distant from the "correct" level than those of simulation. Consequently, the method of simulation gives more correct results for the $\mathrm{OH}^{-}+\mathrm{CO}_{3}{ }^{2-}$ system while the method of determination cannot be recommended because of its high systematic errors in carbonate analysis.

The systematic error naturally increases with decreasing fractions of the analyzed ions. In Figure 3(c), the trend of systematic errors is shown by means of solid lines for the 
TABLE 3: Average values of the "measured/weighted" ratios for each ion in the mixture before and after correction of systematic errors.

\begin{tabular}{|c|c|c|c|c|}
\hline \multirow{2}{*}{ System } & \multirow{2}{*}{ Ions } & \multirow{2}{*}{ Method } & \multicolumn{2}{|c|}{ "Measured/weighted" ratio } \\
\hline & & & Before correction & After correction \\
\hline \multirow{4}{*}{$\mathrm{OH}^{-}+\mathrm{BH}_{4}^{-}+\mathrm{BO}_{2}^{-}$} & \multirow{2}{*}{$\mathrm{OH}^{-}$} & Differentiation & 0.959 & 1.000 \\
\hline & & Simulation & 0.956 & 1.001 \\
\hline & \multirow{2}{*}{$\mathrm{BH}_{4}^{-}+\mathrm{BO}_{2}^{-}$} & Differentiation & 1.023 & 1.008 \\
\hline & & Simulation & 1.012 & 1.004 \\
\hline \multirow{2}{*}{$\mathrm{OH}^{-}+\mathrm{CO}_{3}^{2-}$} & $\mathrm{OH}^{-}$ & Simulation & 0.985 & 1.003 \\
\hline & $\mathrm{CO}_{3}{ }^{2-}$ & Simulation & 1.089 & 0.996 \\
\hline \multirow{3}{*}{$\mathrm{OH}^{-}+\mathrm{BH}_{4}^{-}+\mathrm{BO}_{2}{ }^{-}+\mathrm{CO}_{3}{ }^{2-}$} & \multirow{3}{*}{$\begin{array}{c}\mathrm{OH}^{-} \\
\mathrm{BH}_{4}^{-}+\mathrm{BO}_{2}^{-} \\
\mathrm{CO}_{3}{ }^{2-}\end{array}$} & Simulation & 0.874 & 0.958 \\
\hline & & Simulation & 1.040 & 0.992 \\
\hline & & Simulation & 0.934 & 1.008 \\
\hline
\end{tabular}

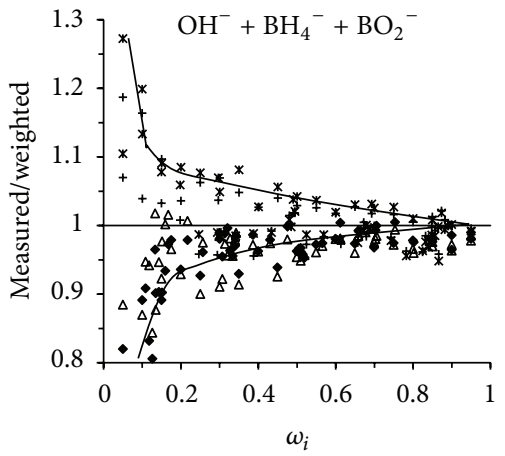

- $\mathrm{OH}^{-}$simulation

$+\mathrm{BH}_{4}^{-}+\mathrm{BO}_{2}^{-}$simulation

- Norm

$\triangle \mathrm{OH}^{-}$differentiation

* $\mathrm{BH}_{4}{ }^{-}+\mathrm{BO}_{2}{ }^{-}$differentiation

(a)

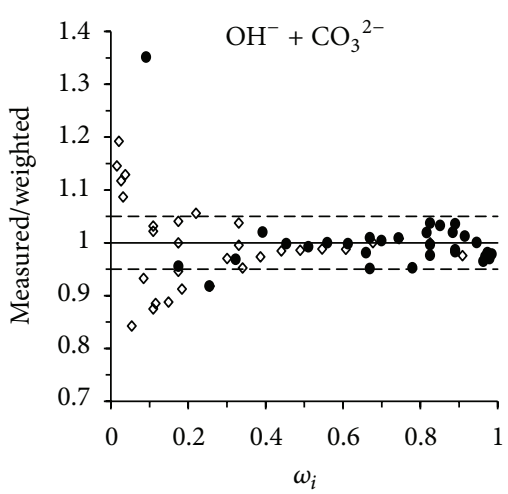

- $\mathrm{OH}^{-}$simulation + correction

$\diamond \mathrm{CO}_{3}{ }^{2-}$ simulation + correction

- Norm

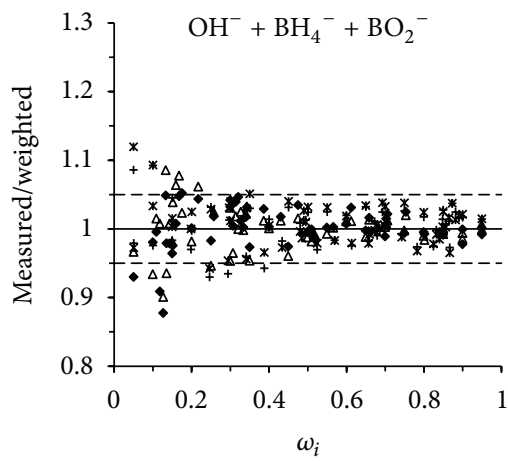

- $\mathrm{OH}^{-}$simulation

$+\mathrm{BH}_{4}{ }^{-}+\mathrm{BO}_{2}{ }^{-}$simulation + correction

- Norm

$\Delta \mathrm{OH}^{-}$differentiation + correction

* $\mathrm{BH}_{4}^{-}+\mathrm{BO}_{2}{ }^{-}$differentiation + correction

(b)

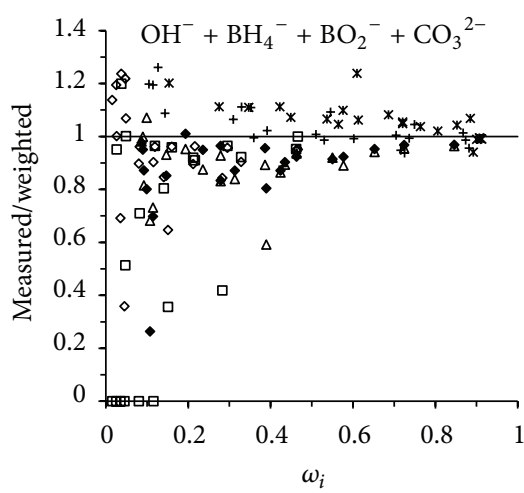

- $\mathrm{OH}^{-}$simulation

$+\mathrm{BH}_{4}^{-}+\mathrm{BO}_{2}^{-}$simulation

- Norm

$\triangle \mathrm{OH}^{-}$differentiation

* $\mathrm{BH}_{4}{ }^{-}+\mathrm{BO}_{2}{ }^{-}+\mathrm{CO}_{3}{ }^{2-}$ differentiation

- $\mathrm{CO}_{3}{ }^{2-}$ simulation

- $\mathrm{CO}_{3}{ }^{2-}$ differentiation

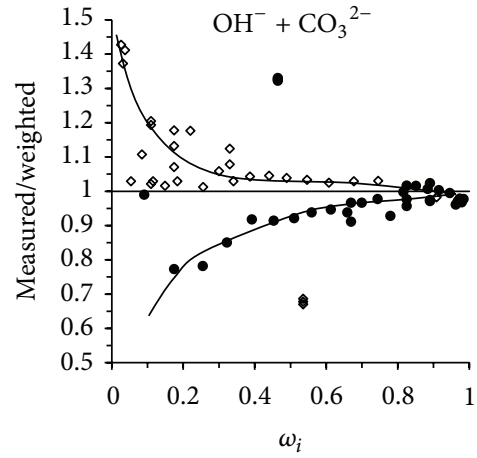

- $\mathrm{OH}^{-}$simulation

$\diamond \mathrm{CO}_{3}{ }^{2-}$ simulation

- Norm

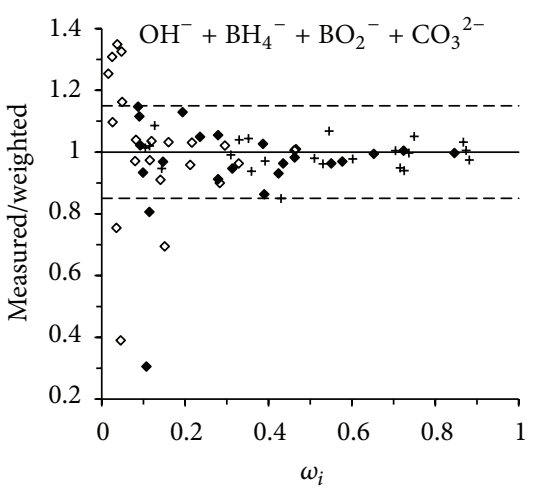

- $\mathrm{OH}^{-}$simulation + correction

$+\mathrm{BH}_{4}{ }^{-}+\mathrm{BO}_{2}{ }^{-}$simulation + correction

- Norm

$\diamond \mathrm{CO}_{3}{ }^{2-}$ simulation + correction

(d)

(e)

(f)

FIGURE 3: Dependence of the "measured/weighted" ratios for anions on their mole fraction $\omega_{i}$ in the mixture: (a) for the $\mathrm{OH}^{-}+\mathrm{BH}_{4}{ }^{-}+$ $\mathrm{BO}_{2}{ }^{-}$system before correction of systematic errors; (b) for the $\mathrm{OH}^{-}+\mathrm{BH}_{4}^{-}+\mathrm{BO}_{2}{ }^{-}$system after correction of systematic errors; (c) for the $\mathrm{OH}^{-}+\mathrm{CO}_{3}{ }^{2-}$ system before correction of systematic errors; (d) for the $\mathrm{OH}^{-}+\mathrm{CO}_{3}{ }^{2-}$ system after correction of systematic errors; (e) for the $\mathrm{OH}^{-}+\mathrm{BH}_{4}^{-}+\mathrm{BO}_{2}{ }^{-}+\mathrm{CO}_{3}{ }^{2-}$ system before correction of systematic errors; (f) for the $\mathrm{OH}^{-}+\mathrm{BH}_{4}{ }^{-}+\mathrm{BO}_{2}{ }^{-}+\mathrm{CO}_{3}{ }^{2-}$ system after correction of systematic errors. The solid lines show the average trend of errors. The dotted lines show the error interval for the method of simulation. 
method of simulation. The following equations have been suggested for compensation of this trend:

$$
\begin{aligned}
& \beta_{\mathrm{OH}^{-}}=\left[2.9-1.9 \omega_{\mathrm{OH}^{-}}^{-0.055}\right]^{-1}, \\
& \beta_{\mathrm{CO}_{3}{ }^{2-}}=\left[7.5 \omega_{\mathrm{CO}_{3}{ }^{2-}}^{-0.01}-6.5\right]^{-1} .
\end{aligned}
$$

After analysis and the determination of the $n_{\mathrm{OH}^{-}}$and $n_{\mathrm{CO}_{3}{ }^{2-}}$ values, a correction procedure is carried out by formula (24). Figure 3(d) shows the result of such correction. The systematic error is completely compensated (Table 3 ). All points lie within the "measured/weighted" range 0.95-1.05 for the anionic fractions within $0.4<\omega_{i}<1$; that is, the random error does not exceed $5 \%$ and the random scattering does not exceed $12 \%$ when $0.15<\omega_{i}<0.4$. If the fraction of carbonate is less than 0.15 , the reliability of its analysis decreases because of the high random dispersion; therefore, it is required to increase the number of replicate samples. The direct titrimetric analysis of carbonate becomes impossible when $\omega_{\mathrm{CO}_{3}{ }^{2-}}<0.015$.

A feature of titration of alkaline-borohydride-boratecarbonate solutions is the existence of three weak leaps on the titration curve (Figure $1(\mathrm{~d})$ ). The first leap belongs to alkali, while the second belongs to the " $\mathrm{BH}_{4}{ }^{-}+\mathrm{BO}_{2}{ }^{-}+$ $\mathrm{CO}_{3}{ }^{2-}$ " total, and the third one belongs to carbonate ions. Respectively, at the quantification of components by means of the position of peaks on the differential curve, the total

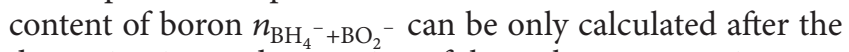
determination and extraction of the carbonate quantity.

The results of our control determination of the anion contents in the $\mathrm{OH}^{-}+\mathrm{BH}_{4}^{-}+\mathrm{BO}_{2}{ }^{-}+\mathrm{CO}_{3}{ }^{2-}$ mixtures by both methods are shown in Figure 3(e). The method of differentiation gives an unsatisfactory result for carbonate, underestimating its content significantly, the mean "measured/weighted" value being 0.615 . The carbonate peak disappears when $\omega_{\mathrm{CO}_{3}{ }^{2-}}<0.15$, which leads to incorrect determination of the $\mathrm{BH}_{4}{ }^{-}+\mathrm{BO}_{2}{ }^{-}$total. Therefore, for the $\mathrm{OH}^{-}+\mathrm{BH}_{4}{ }^{-}+\mathrm{BO}_{2}{ }^{-}+\mathrm{CO}_{3}{ }^{2-}$ system (the highly carbonated and discharged fuel), the method of differentiation cannot be recommended because of its large systematic errors in carbonate analysis and the method of simulation is only suggested for use. The mean "measured/weighted" values are shown in Table 3. The determination accuracy is 0.874 for $\mathrm{OH}^{-}$ions, 1.040 for the $\mathrm{BH}_{4}{ }^{-}+\mathrm{BO}_{2}{ }^{-}$total, and 0.934 for $\mathrm{CO}_{3}{ }^{2-}$ ions. After correction, these parameters become 0.958 , 0.992 , and 1.008 , respectively. The correcting coefficients are

$$
\begin{gathered}
\beta_{\mathrm{OH}^{-}}=\left[1.98-\omega_{\mathrm{OH}^{-}}^{-0.05}\right]^{-1}, \\
\beta_{\left(\mathrm{BH}_{4}{ }^{-}+\mathrm{BO}_{2}{ }^{-}\right)}=\left[\omega_{\mathrm{BH}_{4}{ }^{-}+\mathrm{BO}_{2}{ }^{-}}^{-0.05} 0.03\right]^{-1}, \\
\beta_{\mathrm{CO}_{3}{ }^{2-}}=\left[1.95-\omega_{\mathrm{CO}_{3}{ }^{2-}}^{-0.01}\right]^{-1} .
\end{gathered}
$$

The systematic error is thus compensated; however, the random scattering of the points is higher than with more simple options. The random dispersion for alkali and boron does not exceed $15 \%$ (all points are within $0.85-1.15$ ); however, it is only fair for carbonate when $\omega_{\mathrm{CO}_{3}}{ }^{2-}>0.1$. If the carbonate content is less than 0.1 , its semiquantitative analysis is only possible. But very small amounts of carbonate will not affect the functioning of DBFC and only higher concentrations of carbonate exceeding the solubility limit can be deposited in the electrode to hinder the functioning of DBFC.

\section{Conclusions}

The analytic technique presented in our paper includes taking a small fuel sample from DBFC and performing two types of titrations (acid-base and iodometric ones) which supplement each other. The necessity of exactly two techniques of titration is due to the fact that iodometric titration determines the $\mathrm{BH}_{4}{ }^{-}$quantity in the sample only, while the quantities of other fuel components are provided by acid-base titration $\left(\mathrm{OH}^{-}, \mathrm{BO}_{2}{ }^{-}, \mathrm{CO}_{3}{ }^{2-}\right)$. Therefore, the joint application of these titration techniques allows one to most fully quantify the current state of fuel in the process of DBFC functioning. The determination correctness of the technique has been shown on artificial mixtures with a wide variation of their composition. The average error depends on the number of components and their ratio in the mixture. The investigation results show that in the most complex case of highly carbonated and discharged fuel the maximal error of determination does not exceed $15 \%$.

\section{Conflict of Interests}

The authors declare that there is no conflict of interests regarding the publication of this paper.

\section{Acknowledgment}

The authors would like to gratefully acknowledge the Russian Foundation for Basic Research for financial support (Project no. 12-03-31802).

\section{References}

[1] J. B. Lakeman, A. Rose, K. D. Pointon et al., "The direct borohydride fuel cell for UUV propulsion power," Journal of Power Sources, vol. 162, no. 2, pp. 765-772, 2006.

[2] C. P. de Leon, F. C. Walsh, D. Pletcher, D. J. Browning, and J. B. Lakeman, "Direct borohydride fuel cells," Journal of Power Sources, vol. 155, no. 2, pp. 172-181, 2006.

[3] R. Aiello, J. H. Sharp, and M. A. Matthews, "Production of hydrogen from chemical hydrides via hydrolysis with steam," International Journal of Hydrogen Energy, vol. 24, no. 12, pp. 1123-1130, 1999.

[4] S. C. Amendola, S. L. Sharp-Goldman, M. S. Janjua et al., "Safe, portable, hydrogen gas generator using aqueous borohydride solution and Ru catalyst," International Journal of Hydrogen Energy, vol. 25, no. 10, pp. 969-975, 2000.

[5] H. I. Schlesinger, H. C. Brown, A. E. Finholt, J. R. Gilbreath, H. R. Hoekstra, and E. K. Hyde, "Sodium borohydride, its hydrolysis and its use as a reducing agent and in the generation of hydrogen," Journal of the American Chemical Society, vol. 75, no. 1, pp. 215-219, 1953. 
[6] S. C. Amendola, P. Onnerud, M. T. Kelly, P. J. Petillo, S. L. Sharp-Goldman, and M. Binder, "Novel high power density borohydride-air cell," Journal of Power Sources, vol. 84, no. 1, pp. 130-133, 1999.

[7] B. H. Liu and Z. P. Li, "Current status and progress of direct borohydride fuel cell technology development," Journal of Power Sources, vol. 187, no. 2, pp. 291-297, 2009.

[8] B. H. Liu and Z. P. Li, "A review: hydrogen generation from borohydride hydrolysis reaction," Journal of Power Sources, vol. 187, no. 2, pp. 527-534, 2009.

[9] B. Weng, Z. Wu, Z. Li, H. Yang, and H. Leng, "Hydrogen generation from noncatalytic hydrolysis of $\mathrm{LiBH} 4 / \mathrm{NH} 3 \mathrm{BH} 3$ mixture for fuel cell applications," International Journal of Hydrogen Energy, vol. 36, no. 17, pp. 10870-10876, 2011.

[10] A. E. Sanli, I. Kayacan, B. Z. Uysal, and M. L. Aksu, "Recovery of borohydride from metaborate solution using a silver catalyst for application of direct rechargable borohydride/peroxide fuel cells," Journal of Power Sources, vol. 195, no. 9, pp. 2604-2607, 2010.

[11] R. Jamard, J. Salomon, A. Martinent-Beaumont, and C. Coutanceau, "Life time test in direct borohydride fuel cell system," Journal of Power Sources, vol. 193, no. 2, pp. 779-787, 2009.

[12] J.-H. Wee, "A comparison of sodium borohydride as a fuel for proton exchange membrane fuel cells and for direct borohydride fuel cells," Journal of Power Sources, vol. 155, no. 2, pp. 329-339, 2006.

[13] A. V. Churikov, K. V. Zapsis, V. V. Khramkov, M. A. Churikov, M. P. Smotrov, and I. A. Kazarinov, "Phase diagrams of the ternary systems $\mathrm{NaBH}_{4}+\mathrm{NaOH}+\mathrm{H}_{2} \mathrm{O}, \mathrm{KBH}_{4}+\mathrm{KOH}+\mathrm{H}_{2} \mathrm{O}$, $\mathrm{NaBO}_{2}+\mathrm{NaOH}+\mathrm{H}_{2} \mathrm{O}$, and $\mathrm{KBO}_{2}+\mathrm{KOH}+\mathrm{H}_{2} \mathrm{O}$ at $-10^{\circ} \mathrm{C}$," Journal of Chemical and Engineering Data, vol. 56, no. 1, pp. 9$13,2011$.

[14] A. V. Churikov, K. V. Zapsis, V. V. Khramkov, M. A. Churikov, and I. M. Gamayunova, "Temperature-induced transformation of the phase diagrams of ternary systems $\mathrm{NaBO}_{2}+\mathrm{NaOH}$ $+\mathrm{H}_{2} \mathrm{O}$ and $\mathrm{KBO}_{2}+\mathrm{KOH}+\mathrm{H}_{2} \mathrm{O}$," Journal of Chemical and Engineering Data, vol. 56, no. 3, pp. 383-389, 2011.

[15] A. V. Churikov, K. V. Zapsis, A. V. Ivanishchev, and V. O. Sychova, "Temperature-induced transformation of the phase diagrams of ternary systems $\mathrm{NaBH}_{4}+\mathrm{NaOH}+\mathrm{H}_{2} \mathrm{O}$ and $\mathrm{KBH}_{4}$ $+\mathrm{KOH}+\mathrm{H}_{2} \mathrm{O}$," Journal of Chemical and Engineering Data, vol. 56, no. 5, pp. 2543-2552, 2011.

[16] G. Rostamikiaa and M. J. Janik, "Direct borohydride oxidation: mechanism determination and design of alloy catalysts guided by density functional theory," Energy \& Environmental Science, vol. 3, pp. 1262-1274, 2010.

[17] B. Sljuki, J. Miliki, D. M. F. Santosa, and C. A. C. Sequeira, "Carbon-supported $\mathrm{Pt}_{0.75} \mathrm{M}_{0.25}(\mathrm{M}=\mathrm{Ni}$ or $\mathrm{Co})$ electrocatalysts for borohydride oxidation," Electrochim Acta, vol. 107, pp. 577583, 2013

[18] B. H. Liu, J. Q. Yang, and Z. P. Li, "Concentration ratio of $\left[\mathrm{OH}^{-}\right] /\left[\mathrm{BH}_{4}^{-}\right]$: a controlling factor for the fuel efficiency of borohydride electro-oxidation," International Journal of Hydrogen Energy, vol. 34, no. 23, pp. 9436-9443, 2009.

[19] A. V. Churikov, A. V. Ivanishchev, I. M. Gamayunova, and A. V. Ushakov, "Density calculations for $(\mathrm{Na}, \mathrm{K}) \mathrm{BH}_{4}+(\mathrm{Na}$, $\mathrm{K}) \mathrm{BO}_{2}+(\mathrm{Na}, \mathrm{K}) \mathrm{OH}+\mathrm{H}_{2} \mathrm{O}$ solutions used in hydrogen power engineering," Journal of Chemical and Engineering Data, vol. 56, no. 11, pp. 3984-3993, 2011.

[20] A. V. Churikov, V. O. Romanova, M. A. Churikov, and I. M. Gamayunova, "The model of fuel transformation at discharge of direct borohydride fuel cell," International Review of Chemical Engineering, vol. 4, pp. 263-268, 2012.

[21] A. V. Churikov, I. M. Gamayunova, K. V. Zapsis, M. A. Churikov, and A. V. Ivanishchev, "Influence of temperature and alkalinity on the hydrolysis rate of borohydride ions in aqueous solution," International Journal of Hydrogen Energy, vol. 37, no. 1, pp. 335-344, 2012.

[22] Z. P. Li, B. H. Liu, K. Arai, and S. Suda, "A fuel cell development for using borohydrides as the fuel," Journal of the Electrochemical Society, vol. 150, no. 7, pp. A868-A872, 2003.

[23] Y. Wang, P. Hea, and H. Zhou, "A novel direct borohydride fuel cell using an acid-alkaline hybrid electrolyte," Energy \& Environmental Science, vol. 3, no. 10, pp. 1515-1518, 2010.

[24] J. Ma, N. A. Choudhury, and Y. Sahai, "A comprehensive review of direct borohydride fuel cells," Renewable and Sustainable Energy Reviews, vol. 14, no. 1, pp. 183-199, 2010.

[25] R. Bruhlmann and L. Piatti, "An improved method for the titrimetric determination of boron in iron," Chimia, vol. 11, p. 203, 1957

[26] A. Keshan and C. Bimba, "Cobalt-potassium and ammoniumcobalt dodecaborate," Izvestiya Akademii Nauk Latvijskoj SSR, p. 115, 1954.

[27] J. Czakow, T. Steciak, and O. Szczebinska, “The spectral determination of trace amounts of impurities in the solutions with the metal electrodes in the spark mode," Analytical Chemistry, vol. 3, p. 745, 1958.

[28] R. Rosotti, "A fast method for the determination of trace amounts of boron in the steel," Analytical Chemistry, vol. 44, p. 208, 1962.

[29] J. Varka and A. Sklaf, "Application of potentiometric titration. IV. Determination of $\mathrm{B}_{2} \mathrm{O}_{3}$ in glass, enamels and boroncontaining raw materials," Keramik, vol. 7, p. 12, 1957.

[30] D. E. Williams and J. Vilamis, "Stability of the curcumin complex in boron determination," Analytical Chemistry, vol. 33, pp. 1098-1100, 1961.

[31] S. Kertes and M. Lederer, "Paper chromatography of inorganic ions. Rf values in mixtures of butanol and Hbr," Analytica Chimica Acta, vol. 15, no. C, pp. 543-547, 1956.

[32] A. A. Nemodruk and Z. K. Karalova, The Analytical Chemistry of Boron, Nauka, 1964.

[33] C. A. Parker, "Raman spectra in spectrofluorimetry," The Analyst, vol. 84, no. 1000, pp. 446-453, 1959.

[34] C. A. Parker and W. J. Barnes, "Fluorimetric determination of boron: application to silicon, sea water and steel," The Analyst, vol. 85, no. 1016, pp. 828-838, 1960.

[35] M. V. Akhmanova, Methods of Determination and Analysis of Rear Elements, Izdat Akademija Nauk SSSR, 1961.

[36] E. H. Jensen, A Study on Sodium Borohydride, Nyt Nordisk Forlag Amold Busck, Copenhagen, Denmark, 1954.

[37] I. Fatt and M. Tashima, Alkali Metal Dispersions, D Van Nostrand Co Inc., Princeton, NJ, USA, 1961.

[38] D. A. Lyttle, E. H. Jensen, and W. A. Struck, "A simple volumetric assay for sodium borohydride," Analytical Chemistry, vol. 24, no. 11, pp. 1843-1844, 1952.

[39] P. K. Norkus, "Iodometric determination of borohydride," Russian Journal of Analytical Chemistry, vol. 23, pp. 908-911, 1968.

[40] N. N. Mal'ceva and V. S. Khain, Sodium Borohydride Properties and Application, Nauka, 1985. 
[41] C. Harzdorf and O. Steinhauser, "Zur photometrisehen Titration von Fluorid mit Thoriumnitrat," Fresenius' Zeitschrift für Analytische Chemie, vol. 210, no. 2, pp. 106-112, 1965.

[42] W. D. Davis, L. S. Mason, and G. Stegeman, "The heats of formation of sodium borohydride, lithium borohydride and lithium aluminum hydride," Journal of the American Chemical Society, vol. 71, no. 8, pp. 2775-2781, 1949.

[43] S. W. Chaikin, "Direct volumetric assay of sodium borohydride and potassium borohydride," Analytical Chemistry, vol. 25, no. 5, pp. 831-832, 1953.

[44] Ü. Ülkü and G. Somer, "Determination of trace borohydride in basic solutions using differential pulse polarography," Turkish Journal of Chemistry, vol. 33, pp. 657-665, 2009.

[45] H. Celikkan, H. Aydin, and M. L. Aksu, "The electroanalytical determination of sodium borohydride using a gold electrode," Turkish Journal of Chemistry, vol. 29, pp. 519-524, 2005.

[46] M. V. Mirkin and A. J. Bard, "Voltammetric method for the determination of borohydride concentration in alkaline aqueous solutions," Analytical Chemistry, vol. 63, no. 5, pp. 532533, 1991.

[47] D. M. F. Santos and C. A. C. Sequeira, "Potentiometric monitoring of sodium borohydride in aqueous solutions," Ciencia $s$ Tecnologia dos Materials, vol. 20, no. 3-4, pp. 31-34, 2008.

[48] D. M. F. Santos and C. A. C. Sequeira, "Sodium borohydride determination by measurement of open circuit potentials," Journal of Electroanalytical Chemistry, vol. 627, pp. 1-8, 2009.

[49] H. C. Brown and A. C. Boyd Jr., "Argentimetric procedure for borohydride determination," Analytical Chemistry, vol. 27, no. 1, pp. 156-158, 1955.

[50] V. B. Breicis, A. O. Berzina, and L. K. Lepin, "Potentiometric titration of water solutions of sodium borohydride by hydrochloric acid," Scientific Short Letter of Riga Polytechnic Institute, vol. 15, pp. 179-188, 1965/1966.

[51] U. U. Lurie, Handbook on Analytical Chemistry, Khimiya, 1979.

[52] R. A. Lidin, L. L. Andreeva, and V. A. Molochko, Handbook of Inorganic Chemistry Constants of Inorganic Substances, Khimiya, 1987.

[53] R. A. Robinson and R. H. Stokes, Electrolyte Solutions the Measurement and Interpretation of Conductance, Chemical Potential and Diffusion in Solutions of Simple Electrolytes, Butterworths, London, UK, 1959. 


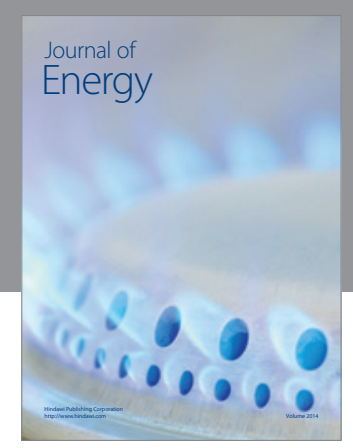

Journal of

Industrial Engineering
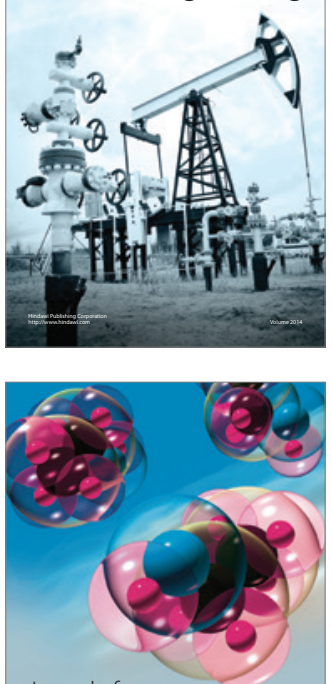

Fuels
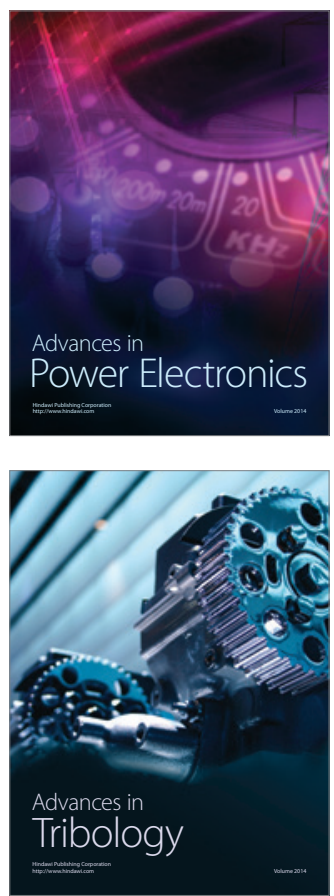

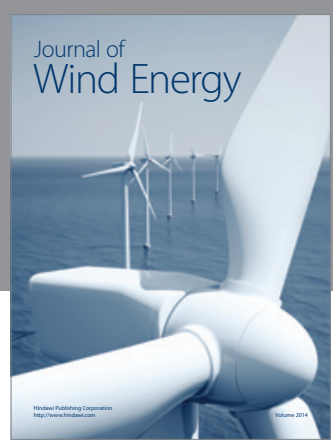

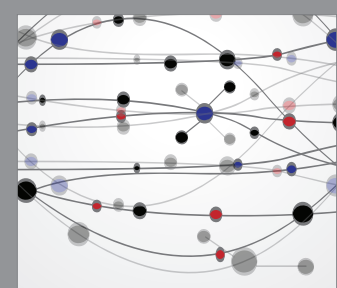

The Scientific World Journal

Submit your manuscripts at http://www.hindawi.com

Journal of

Structures
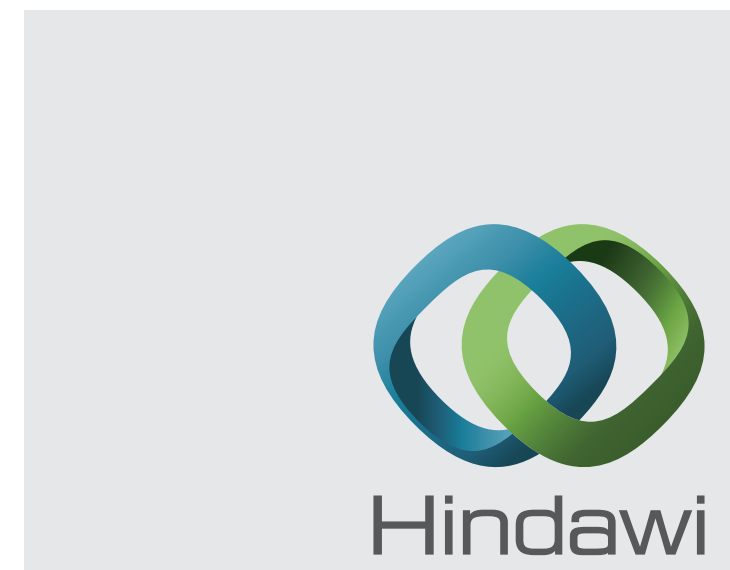

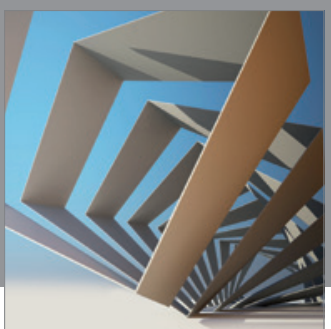

Rotating

Machinery
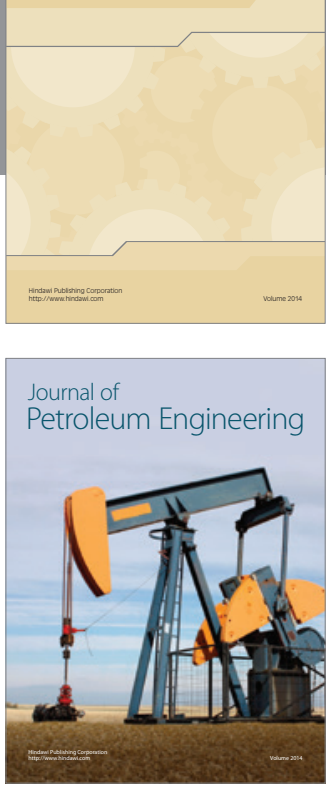

Journal of

Solar Energy
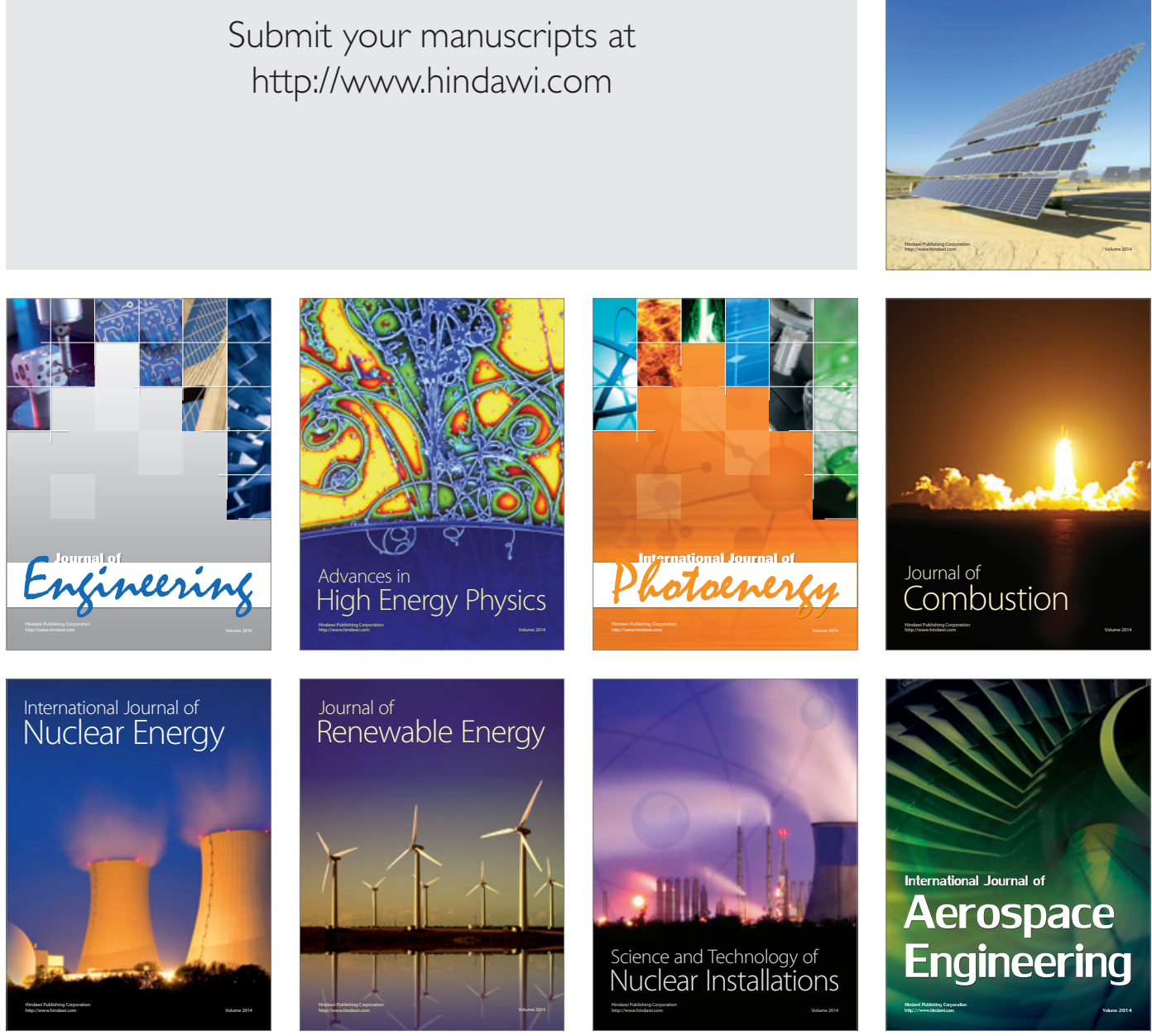